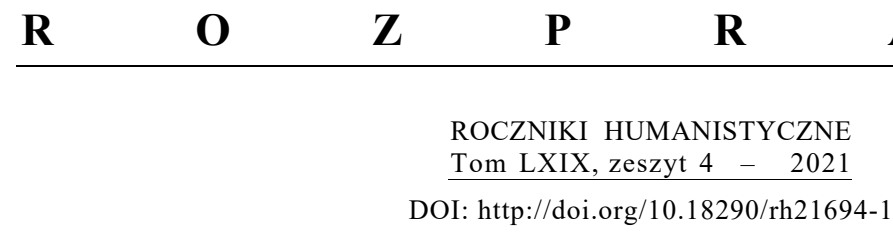

DARIUSZ TABOR CR

\title{
HERMENEUTYKA SZTUKI ŚREDNIOWIECZNEJ: WŁASNA LUB ZAPOŻYCZONA? \\ PRÓBA ZASTOSOWANIA PROCEDUR HERMENEUTYKI FILOZOFICZNEJ DO BADAŃ NAD SZTUKA
}

Hermeneutyka w historii sztuki stała się od pewnego czasu wyraźnym nurtem metodologicznym. Nie jest ona przy tym nurtem jednolitym. Niesie w sobie różne postawy i różne propozycje wzorców badawczych. Na gruncie polskim badania nad hermeneutyką prowadzą Mariusz Bryl i Michał Haake. Obaj badacze krytycznie analizują teksty teoretyczne, jak też podejmują osobiste próby zastosowania wybranych paradygmatów hermeneutycznych do badania dzieł sztuki (Bryl, „Płaszczyzna” 55-84; Suwerenność dyscypliny 433494; Haake, „Jednostka” 25-84; „Powołanie” 37-115; „Obraz” 141-170).

Niniejsze studium jest próbą odpowiedzi na pytanie o możliwość zastosowania hermeneutyki w badaniach nad sztuką średniowieczną. Dystans czasowy epoki, odmienne rysy i wartości jej kultury, bardzo zróżnicowane jakości i struktury dzieł sztuki, wyraźnie wyróżniające się repertorium tematów i typów ikonograficznych, odmiennych aniżeli w innych epokach, każą postawić pytanie o wystarczalność dotychczasowych hermeneutyk wypracowanych na gruncie dyscypliny.

Ks. dr hab. DARIUSz TABor CR, prof. UPJPII - Uniwersytet Papieski Jana Pawła II w Krakowie, Wydział Historii i Dziedzictwa Kulturowego, Katedra Historii Sztuki Starożytnej i Średniowiecznej; adres do korespondencji: ul. Kanonicza 25, 31-00 Kraków; e-mail: dariusz.tabor@, upjp2.edu.pl; ORCID: https://orcid.org/0000-0001-8071-4174. 
HERMENEUTYKI W HISTORII SZTUKI

Hermeneutyka jako sposób postępowania w badaniu dzieł sztuki ma swój początek w myśli Maxa Imdahla. Niemiecki historyk sztuki tworzył od lat 60. nową postawę badawczą - ikonikę, nawiązując do dawniejszych wątków badawczych oraz proponując alternatywę wobec polemicznej historii sztuki (Imdahl, „Über eine narrative Strukturen” 155-173; „Kontingenz” 151-177; Giotto, 111-138). Punktem wyjścia było indywidualne dzieło sztuki, a wraz z nim wszystko to, co zostało dane bezpośrednio do oglądu. Dzieło sztuki jest więc autonomiczną strukturą wizualną, daną widzowi do odbioru w oglądzie. Nie można zapominać o szczególnym podejściu do obrazu. Nie jest on odbiciem swego pozaobrazowego korelatu, lecz swoistym, budowanym według immanentnych zasad systemem, posiadającym swoją wyjątkową tożsamość. Owa tożsamość zasadza się na uznaniu płaszczyznowości i dwuwymiarowości pola obrazowego jako fundamentu wizualności i samoujawniania się dzieła. Aktowi samoujawniania służą linie relacji strukturalnych wewnątrz autonomicznego obrazu.

Max Imdahl wyróżnił dwojakie widzenie obrazu. Pierwszym jest widzenie rozpoznające (niem. das wiedererkennende Sehen), które rozpoznaje w obrazie przedmioty i osoby kreujące świat wyobrażony. Drugim jest widzenie widzące (niem. das sehende Sehen), które pośród osób i przedmiotów dostrzega wyrażone liniami pola obrazowego relacje struktury. Zespół tych linii przybiera postać systemu i nie jest arbitralnie narzucony przez widza. Jest on wyprowadzony z naocznie obserwowalnych i narzucających się elementów struktury obrazu. Odkrycie w kompozycji elementów linii pola umożliwia odczytanie czasowego następstwa wydarzeń, które są ujęte razem w symultaniczności obrazu. Przykładem zastosowania powyższych pojęć do odkrywania ikonicznego sensu obrazu jest rozprawa z 1979 r. na temat swoistych jakości obrazów Giotta (Imdahl, Giotto passim).

Gottfried Boehm stworzył projekt hermeneutyki, który został osadzony $\mathrm{w}$ tradycji hermeneutycznej historii sztuki oraz w tradycji filozoficznej reprezentowanej przez Hansa-Georga Gadamera. Ten badacz w swoim programowym tekście osadził hermeneutykę obrazu na styku między doświadczeniem wizualnym obrazu a językowym medium, które ma go wyrazić. Interpretacja obrazu jest więc przekładem medium wizualnego na medium językowe. Warunkiem tego przekładu jest odnalezienie różnicy między sferą obrazów a sferą języka (Boehm, „Zu einer Hermeneutik” 444-471). Obraz mianowicie jest sposobem przekazu, w który to, co przekazywane, przed- 
miotowe, nie da się oddzielić od tego, co zjawiskowe i co jawi się naocznie w obrazie. Odrzucone zostaje podporządkowanie obrazu językowi i redukcja sensu obrazu do sensu lingwistycznego. Dla obu mediów badacz poszukuje wspólnej podstawy, umożliwiającej przekład dzieła obrazowego na tekst językowy. Jest nią to, co określa słowem Bildlichkeit (obrazowość). W owej obrazowości następuje proces jednoczenia tego, co symultaniczne i następcze, a także tego, co wspólne i różne.

Owa jedność tego, co wspólne, i tego, co różne, w Bildlichkeit umożliwia dwukierunkowy ruch translatorski między obydwoma mediami, czyli nie tylko przekład obrazu na język, ale i wsteczną weryfikację językowego przekładu opartą na powrocie do punktu wyjścia, czyli obrazu. Bildlichkeit pozostaje wspólną podstawą zarówno dla obrazu, jak i dla języka. W przypadku obrazu znika konieczność nieustannego odnoszenia - od znaków do rzeczy oraz od formy do treści i odwrotnie. Owa dwoistość we wspólnej podstawie Bildlichkeit umożliwia odkrycie istoty obrazu. Polega ona na nieustannym konstytuowaniu widzialnym wszystkiego tego, co bez obrazu nigdy nie miałoby szans, aby zostać zauważone i zobaczone.

Istnieje jeszcze jeden ważny postulat hermeneutyki obrazu. Jest nią z jednej stronu samoograniczanie się logosu, dające przestrzeń do ukonstytuowania się obrazu, z drugiej zaś strony pozytywne odniesienie obrazu do mowy, które umożliwia językowe porozumiewanie się. Warunkiem tego porozumiewania się jest mowa, żywy akt komunikowania, odrębny od podmiotowej koncepcji języka.

Właściwe jest przywołanie także trzeciego projektu hermeneutyki, jaki przedstawił Oskar Bätschmann. Wyszedł on od krytyki ikonologii Erwina Panofsky'ego (Bätschmann, „Beiträge zu einem Übergang” 460-484; Einführung passim). Stwierdził on, że trzy etapy badawcze Erwina Panofsky'ego są jedynie redukcjami, sprowadzaniem dzieł sztuki do pozaartystycznych rzeczywistości. Chodziło o redukcję do potocznej rzeczywistości doświadczalnej (opis preikonograficzny), redukcję do rzeczywistości kultury i jej tekstów (analiza ikonograficzna) oraz redukcję do rzeczywistości ostatecznego znaczenia (interpretacja ikonologiczna). Tym samym odczytywanie obrazu jest poddane troistemu dualizmowi - dualizm znaków na poziomie opisu, dualizm intencjonalny znaczenia i tekstu oraz dualizm znaczenia i treści. Ostateczny cel interpretacji, według badacza, ikonologia pokłada w uchwyceniu wszelkich czynników dzieła jawiącego się jako „dokument” jednolitego sensu światopoglądu (Bätschmann, Einführung 16-20). Wynika z tego, że sens istotny dzieła ma więc spoczywać poza nim samym, a potrójne 
a priori $\mathrm{w}$ opisie, analizie i interpretacji (życiowe, kulturowe i kontekstowe) zamykają dzieło przed odczytaniem rzeczywiście tego, co ono niesie. Wynikło z tego przeciwstawienie quasi-wyjaśniania dzieła i jego rozumienia. Owo wyjaśnienie jest jedynie odkryciem historycznych konwencji, które wpłynęły na kształt dzieła. Rozumienie natomiast odkrywa objawiający się obraz. Tak więc interpretacja w procesie hermeneutyki odkrywa nie sens, ale sam obraz (Bätschmann, Einführung 9). Hermeneutyka w wydaniu Oskara Bätschmanna promuje specyficzne doświadczenie oglądowe, które jest odpowiedzią na to, co sam obraz wydobywa z siebie na jaw. Najważniejsze dla niego była autonomiczność dzieła oraz prymat doświadczenia wizualnego.

Czy te trzy hermeneutyki, oferujące określone zestawy narzędzi badawczych, mogą okazać się przydatne do badania sztuki średniowiecznej? Ikonika Maxa Imdahla oferuje model badania dzieła oparty na płaszczyźnie obrazu i planimetrycznym systemie linii pola. Ma on w założeniu ujawnić wewnętrzne relacje między przedstawionymi przedmiotami oraz uchwycić w symultaniczności momenty sekwencji wydarzeń, odkrywając tym samym ich istotę. Czy jednak ów rdzeń wydarzeń można uznać za nośnik sensu? Czy sens obrazu tkwi w nim samym, bo przecież płaszczyzna i system linii pola opisują jedynie strukturę widzialności w jego granicach?

Bildlichkeit - wspólna platforma medium obrazowego i medium językowego - również rodzi wiele pytań. Przekład obrazu na medium językowe wymaga wyjścia poza sferę widzialności, samoograniczenie się jednak logosu i tożsamość obrazu każą zmienić kierunek poszukiwań i przejść od językowego przekładu z powrotem do obrazowości w celu zweryfikowania przekładu. Czy w samym Bildlichkeit, weryfikowanym przez wahadłowy ruch translatorsko-kontrolny, może wytworzyć się sens?

Hermenutyka Oskara Bätschmanna odrzuca redukcję, jakiej poddaje obraz ikonologia, a promuje wszystko to, co dzieło sztuki ujawnia samo z siebie. Autonomiczność dzieła jest warunkiem tego, aby dzieło wyjawiło to, co w nim jest swoiste i jedyne. Rozumienie dzieła w sztuki przeciwstawione quasi-wyjaśnianiu ma umożliwić samoobjawienie się obrazu i rezygnację z traktowania go jako medium, które ujawnia historyczne wybory, narzucające się choćby poprzez temat i typ ikonograficzny. Czy jednak zawartość dzieła, dana badaczowi w samoobjawieniu się obrazu, nie kieruje uwagi ku zewnętrzności obrazu?

Wszystkie te hermeneutyki mają bardzo zbliżony kierunek poszukiwania sensu. Kierują mianowicie swój wysiłek badawczy ku autonomicznej, swoistej, niepowtarzalnej, nieredukowalnej do dyskursu, choć na niego przetłu- 
maczalnej strukturze obrazu. Owszem, odkrycie autonomiczności obrazu, dokonane w nurcie polemiki z ikonologią Erwina Panofsky'ego, jest doniosłym dokonaniem. Nasuwa ono jednak pytanie: czy owa autonomiczność, zasadzająca się na naoczności i komunikowalności tego, co ukazane bezpośrednio, może być jedynym nośnikiem i producentem sensu? Czy jedynie ku niej ma się kierować wysiłek rozumienia?

Dzieło sztuki średniowiecznej, w swej autonomiczności i widzialności, jest uwikłane w splot relacji pozaartystycznych i pozaobrazowych, osadzone mocno w metodzie życia zbiorowego i poddane jest oddziaływaniu wielorakich nurtów myśli i wartości. Czy można więc zredukować jego sens do swoistości dzieła w jego Bildlichkeit, odkrywanym w ruchu translatorskim, lub w planimetrycznym systemie linii, identyfikowanych w widzeniu widzących? Owa redukcja zdaje się zatracać istotne elementy sensu, niedostępne „przetłumaczalnej obrazowości”, systemowi linii pola czy samoobjawieniu się.

Gdy jednak przeanalizujemy wnikliwie linię postępowania badawczego obu formacji hermeneutycznych, dostrzeżemy zadziwiającą, dotychczas nieodkrytą zdolność. System linii pola, konstytuujący symultaniczność, zakłada sekwencyjność wydarzeń. Ta natomiast każe odnieść obraz do wyłaniającej się sekwencyjności narracji. Nasuwa się pytanie: Skąd ta narracja się bierze i gdzie należy szukać jej sensu i zrozumienia?

Dwoistość mediów Gotfrieda Boehma zakłada ruch translacyjny od medium obrazowego do medium językowego i z powrotem od ograniczoności logosu do autonomii i tożsamości obrazu. Moment jednak, w którym operacja poznawcza jest skoncentrowana na medium językowym, daje niesamowitą szansę. Może nastąpić odwrócenie dotychczas zaplanowanego ruchu hermeneutycznego i odniesienie zakończonego już tłumaczenia do innego tekstu, innego tworu mowy czy nawet innego medium, odmiennego od obrazowego i językowego. Może się bowiem okazać, że produkt mowy sformułowany na podstawie Bildlichkeit może formułować pytanie o swój własny sens i będzie domagał się innego tekstu, nawet innego medium w celu odkrycia sensu.

Odrzucenie potrójnej redukcji ikonologii ma prowadzić do uchwycenia autonomiczności dzieła sztuki. Miało ono przemówić tym, co wydobywa samo z siebie. Doświadczenie wizualne, którego prymat zakłada Oskar Bätschmann, ma być otwarciem na to, co objawia obraz. Właśnie owo objawienie może stać się wyjątkową szansą na to, aby w treści tego objawienia rozpocząć poszukiwanie sensu.

Owe trzy momenty - imdahlowska narracja, mowa Gotfrieda Boehma oraz samoobjawienie się obrazu Oskara Bätschmanna - przekonują, że ist- 
nieje droga badawcza poza granicę dzieła sztuki i poza nią należy szukać sensu. Nadal jednak stoimy przed pytaniem: Jaka hermeneutyka pozwoli skutecznie odkrywać sens dzieł sztuki średniowiecznej? Czy któryś z trzech projektów hermeneutycznych byłby w stanie sprostać zadaniu odkrywania sensu dzieła sztuki średniowiecznej? Odpowiedzi na te pytania oraz zdolność powyżej przeanalizowanych hermeneutyk do wyjścia poza granice dzieła sztuki wymagają odrębnych badań i nie są przedmiotem niniejszego przedłożenia. Zasadniczy kierunek badań oraz ograniczenia skłaniają obecnie do domniemania, że zastosowanie owych hermeneutyk w obszarze sztuki wieków średnich może przynieść nikłe jedynie lub ułomne rezultaty. Hipoteza o ich zdolności do wyprowadzenia kręgu badawczego na zewnątrz musi być zweryfikowana. Dlatego piszący te słowa zdecydował się podjąć próbę stworzenia projektu hermeneutyki opartej na filozoficznej hermeneutyce Hansa-Georga Gadamera (passim) z pewnymi odniesieniami do myśli Martina Heideggera (passim).

\section{UPRZEDZENIE CZY PRZEDROZUMIENIE}

Podstawowym warunkiem operacji hermeneutycznych jest istnienie konglomeratu przekonań, które towarzyszą badanemu dziełu przy pierwszym oglądzie. Zwykle określane są one heideggerowskimi pojęciami - „wstępny zasób” (Vorhaben), „wstępny ogląd” (Vorsicht) i „wstępne pojęcie” (Vorgriff) (Heidegger 192-194). Rodzi się od razu pytanie: czy oddają one adekwatnie stan wiedzy u początków badań?

Owo początkowe, wyjściowe poznanie nie jest luźnym zestawem wyników przypadkowych obserwacji i stwierdzeń, lecz jest częścią operacji poznawczej opisanej poprzez metaforę kręgu Jest ono też początkowym, wyjściowym wyposażeniem badacza, który staje w obliczu przedmiotu badań - dzieła sztuki. Opisany krąg zakłada wyjście od tego przekonania, przedarcie się przez strukturę badanego dzieła i powrót do punktu wyjścia, lecz już otoczonego bardziej adekwatnym i zgodnym z jego bytem pojęciem. Jest to ruch po okręgu opisany przez Heideggera (194-197) i rozwinięty przez Gadamera (400-412).

Konieczne jest postawienie dwóch pytań. W pierwszym pytamy o zawartość owego pierwotnego poznania czy też przedpoznania. Drugie pytanie docieka tego, co się dzieje między opuszczeniem pierwotnej postawy poznawczej a powrotem do przedmiotu, lecz już opisanego przez nowe pojęcie. 
Trzeba poszukać odpowiedzi na pierwsze z nich. Owa początkowa jakość nie jest jakimkolwiek dowolnym (według Gadamera) stwierdzeniem. Jest ona przyswojoną wiedzą, strukturą poznania, określoną przez dotychczasowe, komunikowalne międzyosobowo badania i wpisane w strukturę kultury. Owej wiedzy przysługuje cecha rzeczowości, tak doceniana przez Gadamera (370-372). Aby ta wiedza mogła wyprowadzić ruch po okręgu, musi być solidna, mocna, lecz i ograniczona.

Można teraz podjąć próbę odpowiedzi na drugie pytanie. Przez jakie struktury przebiega poznawczy ruch po okręgu? Pierwsza rzeczą, jaką postuluje Gadamer jest powrót do tekstu (372). Jest to zagłębienie się w strukturę oraz zestawienie tego, co już o tekście, w naszym przypadku o dziele sztuk plastycznych, wiemy, albo tego, o czym jesteśmy przekonani, oraz tego, co samo dzieło/tekst nam mówi i otwiera przed nami. Można tu przywołać opis owego ruchu, który biegnie od części do całości i od całości do części, jednakże taki opis ruchu Gadamerowi nie wystarcza.

Kolejnym jego postulatem jest krytyczne stosowanie języka. Przestrzega on przez bezrefleksyjnym korzystaniem z kodów, które znamy. Chodzi o to, aby przyswojonym przez nas znaczeń nie nakładać na elementy struktury, którą badamy. Ostatnim postulatem jest otwartość na pogląd tekstu. Rozumienie ma być rezultatem konsekwentnego i upartego wsłuchiwanie się w orędzie tekstu. Początkowe poznanie nie powinno blokować tego, co tekst sam lub samo dzieło sztuki miałoby do powiedzenia badaczowi. Gadamer używa tu pojęcia „inności” (372-373). Jest nią to, co spotykamy, gdy przedzieramy się przez gąszcz tekstu lub dzieła sztuki. Wstępne rozpoznanie i związany z nim zobiektywizowany stan wiedzy poprzedzającej ruch po okręgu zostaje skonfrontowany $\mathrm{z}$ tym wszystkim, co $\mathrm{w}$ dziele sztuki jest właściwe tylko dla niego i niepowtarzalne, a osadzone w jego strukturze i zawartości.

Stwierdzamy więc, że ruch po okręgu, którego warunkiem jest wstępne poznanie, umożliwia stworzenie nowej jakości poznawczej, zwanej już przez Heideggera „projektem” (186-187). Gadamer stwierdza, że „projekt” jest narzędziem zrozumienia tekstu, a spojrzenie na tekst, na badane przedmioty, ma zaowocować właśnie nakreśleniem pewnej nowej wizji sensu (369). „Projekt”, czyli nowy zestaw pojęć i nowa wizja przedmiotu poznania, jest ograniczony. Jest stworzony w konfrontacji z przedpoznaniem i przedprojektem, ale czerpie jedynie $\mathrm{z}$ bezpośrednich danych tekstu, ze struktury i z samej naoczności dzieła sztuki. Operacje dokonywane na kręgu są ograniczone do struktury i naoczności dzieła. Dokładna jednak analiza naoczności pozwoli nam stwierdzić elementy, które odnoszą poznającego do rzeczywistości zewnętrznych w stosunku do dzieła. 


\section{SPIRALA WYPROWADZAJĄCA POZNANIE NA ZEWNĄTRZ}

Wyprowadzenie kręgu na zewnątrz dzieła sztuki nie odbywa się w sposób ślepy i dowolny. Ma on określony przebieg, a zewnętrzność nie jest czymś nieokreślonym. Czym jest owa zewnętrzna w stosunku do dzieła rzeczywistość, przez którą ma przebiegać linia kręgu?

Pierwszym komponentem zewnętrzności jest, jak ją określa Gadamer, swoista forma autorytetu, zwana tradycją (387-388). Twierdzi on, że zanurzony w historii byt podlega przemożnemu wpływowi tradycji. Wywodzi on stąd postulat, aby w humanistycznej hermeneutyce badaniom nad przedmiotem nie przeciwstawiać sposobu, w jaki człowiek odnosi się do swej przeszłości. Nie można dojść do prawidłowego rozumienia przedmiotu, jeśli własną dziejowość zalicza do uprzedzeń, z których należy się uwolnić.

Działanie tradycji należy, według tegoż filozofa, do istoty humanistyki. W jej badaniach nie ma sprzeczności między świadomością historyczną i dystansem czasowym a oddziaływaniem tradycji (Gadamer 389-390). Gadamer opisuje badanie, którym rządzi oczekiwanie sensu stworzone przez kontekst dzieła, czyli to wszystko, co istniało wcześniej. Owo oczekiwanie ulega rozszerzeniu, gdy jego poszukiwania zataczają coraz to szersze kręgi, które dotykają kontekstu życia autora, gatunku dzieła, sztuk plastycznych, całej literatury czy nawet całości kultury.

Pojedynczy tekst, rozumiany szeroko, czy dzieło sztuki odnajduje swój sens nie tylko w swej strukturze i bezpośrednio danej naoczności, ale szuka go w rzeczywistościach, do których należy, których jest częścią. Zawsze jest jednak określonym, niepowtarzalnym momentem należącym do całości życia duchowego autora, co więcej - do całości dziedzictwa. Niezwykle istotnym postulatem jest uchwycenie pełni zrozumienia. Tekst jest zrozumiały tylko wtedy, gdy nie pozostawia luk w zrozumieniu. Podstawą tego jest wstępne rozumienie tekstu.

Te stwierdzenia pozwolą nam zrekonstruować algorytm operacji hermeneutycznych według Gadamera. Podstawą jest bycie związanym z rzeczą i jego przekazem. Wstępne uchwycenie sensu generuje ruch po okręgu. Krąg ten, wychodząc od struktury dzieła, dotyka poprzedzających do tekstów, usytuowanych na historycznej linii czasu. Rzecz wyrażająca swój przekaz wchodzi w kontakt $\mathrm{z}$ tradycją. Owo wchodzenie w kontakt przybiera kształt szeregu kręgów przenikających teksty i dzieła tradycji oddalone czasowo od naszego tekstu czy dzieła. Odkrywana jest wtedy wspólność przekonań. Właśnie owa wspólność przekonań jest podstawą sensu, który jest budo- 
wany, począwszy od zarysowanej na wstępie pełni, lecz nieustannie dopełniany poprzez stwierdzanie coraz dalszej i coraz głębszej wspólnoty dzieła i tradycji. Najbardziej odpowiednią metaforą tego opisu byłaby więc spirala lub zestaw koncentrycznych kręgów. Konfrontując swoje wstępne uchwycenie przedmiotu, ruch badacza stwierdza wspólność sensu dzieła wyjściowego i dzieła poprzedzającego. Konstytuuje tym samym przynależność do tradycji. Dwie rzeczy są tu istotne. Pierwszą jest bycie związanym z rzeczą, czyli wejście w strukturę oraz przekaz badanej rzeczy, np. dzieła sztuki. Drugą jest wspólność podstawowa przekonań charakterystyczna dla dzieła badanego i tej sfery, która ją poprzedza, a która została dostrzeżona poprzez kontakt $\mathrm{z}$ tradycją.

Postulaty metodologiczne Gadamera wymagają wrażliwości na pełnię i strukturę analizowanego tekstu lub dzieła. Określają one jako cel badań pełnię sensu. Domagają się odnoszenia przedmiotu badań do tradycji, lecz pojętej jako konkretne teksty o wspólności przekonań i orędzia z badanym przedmiotem. Kierunek badań jednak, choć cenny, jest dość jednostronny. Kręgi koncentryczne czy zwoje spirali dotykają jedynie tekstów tradycji nanizanych na linię czasu. Ustanawiają jedyną przynależność i tym samym jednostronny sens.

Bezpośrednie skierowanie się do tradycji, jak to zaleca Gadamer, budzi jednak uzasadnioną wątpliwość. Owszem, wnikliwość w podejściu do struktury dzieła i otwartość na jego niepowtarzalność na drodze do poszukiwania pełni sensu wskazują właściwą drogę badawczą. Czy jednak samo odniesienie do tekstów szeroko pojętej tradycji jest w stanie dotrzeć do pokładów sensu? Tradycja zakłada bowiem dystans czasowy, mniejszy lub większy, od badanego dzieła. Niewspółczesność tradycji i dzieła każe stawiać pytanie o różnice między mentalnością, duchowością i aktywnością obu momentów czasowych. Owszem, nie można pomijać wpływu tradycji na dzieło, ale istnieje domniemanie, że główne rysy sensu znajdują się w otaczającej współczesności, dlatego współczesny dziełu zasób odniesień powinien stać się podstawą badań. Pominięcie w procesie poznawczym otaczającej współczesności byłoby błędem, ponieważ zaprzeczałoby istnieniu dzieła sztuki w swoim pierwotnym środowisku bytowym oraz odrzucało relacje $z$ wszelkimi dziedzinami, rzeczywistościami, które istniały jemu współcześnie i oddziaływały na nie. Dzieło, rozpoczynające swój byt, zostało na początku skonfrontowane $\mathrm{z}$ tym, co go otaczało. Ruch ku tradycji przyjdzie dopiero po wniknięciu w strukturę dzieła oraz po jego skonfrontowaniu z tą rzeczywistością - zarówno artystyczną, jak i pozaartystyczną, która istniała już, lub 
rozpoczynała swe istnienie $\mathrm{w}$ momencie zaistnienia dzieła. Odniesienie i droga spirali zostanie poprowadzona ku współczesnej strukturze zwanej horyzontem.

\section{SPIRALA BIEGNĄCA KU HORYZONTOM}

Badania samej struktury dzieła oparte na kolistym algorytmie jest nadal aktualne i doniosłe. Wyniki jednak tych badań będą miały już inny charakter. Będą stanowić owo przedpoznanie wstępne, przekonanie czy nawet „wstępne uchwycenie pełni”. To będzie podstawą, która zainicjuje ruch po okręgach skierowany już na zewnątrz. Poprzez jaką rzeczywistość zewnętrzną zostaną poprowadzone kręgi? To, czego dotknie linia kręgu zostanie określone jako „horyzont”. Czym jest horyzont? Gadamer definiuje to pojęcie jako obszar widzenia, obserwowalny z określonego punktu, który obejmuje wszystko, co ten punkt otacza (415). Jest to widzenie filozoficzne, natomiast dla celów badań historyczno-artystycznych należy sformułować odpowiednio precyzyjną definicję. Jest to rzeczywistość kultury, zbiór tekstów, zestaw dzieł sztuki, konglomerat umiejętności, zespół poglądów, zarówno usystematyzowany w postaci doktryny, jak i ten rozproszony, zbiór wartości, który zostaje przez badacza wybrany i skonfrontowany z badanym dziełem. Nasze dzieło, przebadane i określone poprzez wstępne uchwycenie pełni, zostaje postawione pośrodku rzeczywistości, która na pozór nie przystaje do naszego dzieła i jego struktury. „Pozór” ma wielkie znaczenie. Jest on momentem konfrontacji i momentem zaskoczenia, zestawienie bowiem i konfrontacja mogą przynieść nieoczekiwane wyniki. Przykładem takiej konfrontacji może być choćby zestawienie umysłowości monastycznej i duchowości, z wyjątkowym dziełem sztuki, które powstaje pośrodku nich. Analogicznie można skonfrontować życie wewnętrzne i duchowość, które owocują obrazami, oraz kult religijny i liturgię, które są zestawione z powstającymi dla ich potrzeb przedmiotami o walorach artystycznych.

Należy najpierw przeanalizować istotę horyzontu. Horyzont nie jest zwykłym kontekstem, w którym istnieje dzieło sztuki. Nie jest on zwykłą strukturą dzieł, tekstów, artefaktów materialnych, obrazów, tematów, układów społecznych, wśród których dzieło sztuki zaistniało jak w swoim naturalnym otoczeniu. Horyzont jest niezależny od przedmiotu badań. W pierwszym oglądzie dzieło sztuki i jego horyzont są do siebie nieprzystawalne. Różne są struktury obu rzeczywistości, rożne zawartości, odmienne kody i orędzia. 
Zwykle horyzont jest rzeczywistością pozaartystyczną, nieplastyczną i niewizualną. Jest on autonomiczny w stosunku do dzieła, dlatego też zachowuje wewnętrzną strukturę, reguły funkcjonowania, zasoby, wartości i zawartość swego orędzia. Wszystko to jest respektowane przez badacza.

Horyzont konfrontowany $\mathrm{z}$ dziełem ma już określony kształt i zawartość. Nasuwa się pytanie: co zdecydowało o tym kształcie? Jest on rezultatem odkrycia i wyboru. Odkrycia dokonuje podmiot badający, stwierdzając na początku, że właściwie wszystko, co otacza dzieło sztuki, jest strukturalnie i zawartościowo od niego odmienne i do niego nieprzystające. Po głębszym oglądzie stwierdza jednak, że istnieją w obszarze horyzontu pewne jakości i wartości, które wydają się być styczne z jakościami dzieła. W konsekwencji dokonuje on ich wyboru, wyodrębniając $\mathrm{z}$ całej odmienności otoczenia tylko te jakości, wartości i fragmenty, które chce skonfrontować z dziełem.

Wynika $\mathrm{z}$ tego, że dzieło jest skonfrontowane $\mathrm{z}$ horyzontem na mocy decyzji badacza. Nie jest to jednak decyzja arbitralna i dyktowana jakimś nieskrępowanym skojarzeniem. Badacz staje w miejscu dzieła sztuki, akceptuje jego złożoność, jego zasób i strukturę. Przyjmuje więc wszystko to, co nazywamy przedprojektem poznania, opisanym powyżej. Stając w miejscu dzieła sztuki, utożsamiając strukturę dzieła, jego zwartość ze swym poznaniem pierwotnym, staje razem $\mathrm{z}$ nim w centrum obszaru, który jest otoczony przez horyzont lub horyzonty. Przyjmuje tym samym pewien punkt widzenia skierowany na otaczający horyzont.

Mając ogląd całości horyzontu, czyli otaczającej współczasowej rzeczywistości, wybiera $\mathrm{z}$ niego to, co skonfrontuje $\mathrm{z}$ dziełem, a co wydaje się współbrzmieć z przedpoznaniem. Wynika ona z przyjętej postawy badacza nastawionego na odkrycie sensu dzieła sztuki i podejmowanych prób weryfikacji początkowego znaczenia i początkowego sensu znaczenia. Niezwykle istotne jest to, że horyzont jest zasadniczo tożsamy chronologicznie z dziełem. Nie poprzedza on dzieła na linii czasu, ale współistnieje z nim w tym samym czasie.

Ruch badawczy w kierunku horyzontu nie dokonuje się na okręgu, ale na spirali. Powrót do przedmiotu po przejściu przez tkankę horyzontu domaga się następnego ruchu, ponieważ rezultat pierwszej operacji poznawczej nie wyczerpuje całej złożoności struktury. To wielokrotne przedzieranie się ruchu badawczego przez horyzont każe postawić pytanie o wyniki konfrontacji dzieła $\mathrm{i}$ jego horyzontu oraz o poszerzenie wstępnego uchwycenia i poznania. Jest to również pytanie o sens dzieła i o to, na czym ten sens się zasadza. 
Sens dzieła sztuki zestawionego z horyzontem, który będzie sensem cząstkowym, nie zasadza się ani na dopełnieniu wstępnego obrazu całości. To, co odnajdujemy w dziele po przeprowadzeniu spirali przez horyzont, może być sporym zaskoczeniem dla badacza. Może ono zmodyfikować niektóre, a nawet wszystkie stwierdzenia przedrozumienia. To jednak, co zostało odkryte, będzie tylko wyborem, selektywną kolekcją jakości i wartości pochodzącą z zasobu znaczeń, relacji, kodów przynależnych do horyzontu. Dzieło sztuki nie jest nigdy miniaturą struktury horyzontu lub jakiegokolwiek jego sektora. Wszystko to jednak, co zostało znalezione w dziele sztuki, a co ma swe odpowiedniki i swą genezę w horyzoncie, może stanowić o niepowtarzalnych cechach tego dzieła, o jego indywidualnych znaczeniach. Szczególnie należy to powiedzieć o tych elementach, które stanowiły zaskoczenie dla badacza. Czy jednak tylko to, co odnaleziono w dziele i odkryto następnie w zasobach horyzontu może stanowić o sensie tego dzieła? Wydaje się że nie. Mimo że operacje poznawcze będą ponawiane i spirala ruchu badawczego będzie się zagęszczać, nigdy nie będzie tak, że cały zasób horyzontu zostanie wyczerpany i znajdzie się w swej całości w strukturze dzieła. Odnajdziemy w nim tylko wybrane elementy horyzontu. Te zaś będą się domagać dalszych operacji poznawczych, skonfrontowanie bowiem dzieła $z$ horyzontem okazuje się niewystarczające do odkrycia sensu. W tej sytuacji nasuwa się pytanie o zakres i kształt dalszych operacji poznawczych. Zanim jednak zostanie udzielona odpowiedź na to pytanie, zasadne jest przeprowadzenie przykładowych analiz hermeneutycznych.

\section{HERMENEUTYKA LITURGICZNA: \\ PATENA Z TRZEMESZNA}

Kolista forma pateny, powstałej około 1180 r., a związanej z Trzemesznem (Gniezno, Muzeum Archidiecezjalne) (il. 1), wyraźny podział na zwierciadło oraz kołnierz, obrzeże wydaje się ułatwiać rozeznanie struktury. Tym samym odczytanie orędzia może być ułatwione. Cześć centralna odznacza się większa doniosłością i wagą, ponieważ jest przeznaczona do przyjęcia i zabezpieczenia konsekrowanej hostii. Mniejsza wagę ma szerokie obrzeże. Czy w taki sam sposób należy potraktować przedstawienia, które zajmują wymienione części? Zwierciadło wypełnia przedstawienie Ukrzyżowania wraz z Synagoga i Eklezją. Na obrzeżu znajdują się przedstawienia starotestamentalne - Ofiara Abrahama, Melchizedek, Drabina Jakubowa, Wąz miedziany, Woda ze skały, 
Zwiadowcy w ziemi Kanaan, Gedeon i aniot, Ofiara Manoacha, Eliasz $i$ wdowa $z$ Sarepty (Skubiszewski 77-81). Jaki jest sens tych przedstawień i sens samego przedmiotu? Aby odpowiedzieć na te pytania, należy skonfrontować przedmiot i jego przedstawienia $\mathrm{z}$ horyzontem liturgii.

Liturgia - wydarzenie w życiu Ludu Bożego, wspólnoty wierzących uobecnia najważniejsze momenty dokonanego zbawienia. Spiralna linia dotknie złożonej rzeczywistości, do której należą teksty, przestrzeń, ubiory, przedmioty, gesty, postawy, symbole oraz skomplikowane struktury celebracji. Wśród nich odnajdziemy liturgię eucharystyczną, której patena i kielich są istotnymi, niezbędnymi elementami. Jakiego segmentu liturgii eucharystycznej musi dotknąć linia spiralna, aby przynieść przynajmniej częściowe zrozumienie przedstawienia pateny? Pod względem kulturowym missa, chodzi bowiem o mszę rzymsko-galijską, a następnie o celebrację przyjętą w świecie zachodnim na początku drugiego tysiąclecia, jest strukturą retoryczną i dramatyczną, która w swym przebiegu ujawnia centralne rzeczywistości chrześcijaństwa (Martimort 122, 156-168; Meyer, 196-198, 204-206). Średniowieczna liturgia eucharystyczna ma w swej strukturze dwie części: missa catechumenorum i missa fidelium. Centralną częścią missa fidelium jest $\mathrm{Ca}$ non Romanus, modlitwa eucharystyczna mająca swoją genezę $\mathrm{w} \mathrm{V}$ wieku (Jungmann 127-340). Cezurą dzielącą ją na część zstępującą i wstępującą jest institutio, czyli słowa ustanowienia. Dotyczą one chleba i wina, a odnoszą się do męki Chrystusa - wydanego ciała i przelanej krwi. To daje nam zrozumienie, dlaczego w środkowej partii, gdzie spoczywa hostia, przedstawiono Ukrzyżowanie. Institutio, czyli ustanowienie, ujawnia centralny moment zbawienia - mękę i śmierć Chrystusa na krzyżu. Tak więc w newralgicznym miejscu liturgii eucharystycznej słowa ustanowienia i grawerowany obraz na zwierciadle pateny przynoszą zespolenie dzieła i jego horyzontu, a tym samym otwierają na doświadczenie zrozumienia. Jest to jednak, jak już zostało powiedziane, sens cząstkowy. Skąd może wywodzić się sens pełny, odczytany po zetknięciu się obrazu i słów liturgii? Aby znaleźć odpowiedź na to pytanie, należy szukać interpretacji i rozumienia samej liturgii $\mathrm{w}$ jej formach w historii poprzedzającej patenę.

\section{HERMENEUTYKA EGZEGETYCZNA: PSAŁTERZ TRZEBNICKI}

Miniatura na karcie 68r psałterza trzebnickiego (Wrocław, Biblioteka Uniwersytecka, IF 440) (il. 2) przedstawia Ukrzyżowanie, gdzie obok krzyża 
stoją Maryja, matka Jezusa i św. Jan Ewangelista. Przedstawienie jest dość rozpowszechnione. Należy jednak postawić sobie pytanie, dlaczego znalazło się w tym określonym miejscu księgi. Otóż miniatura znajduje się przy tekście psalmu 68, który rozpoczyna się następująco: Salvum me fac deus, quoniam intraverunt aquae usque ad animam meam. Infixus sum in limae profundi et non est substantia (Ps 68, 1) (Tabor, „Psałterz trzebnicki” 108120; „Od lectio divina” 179-194). Zestawienie miniatury i nawet całego tekstu psalmu zaskakuje i zdaje się ukazywać niespójność treści psalmu i treści miniatury. Aby jednak szukać zrozumienia, należy zestawić miniaturę i $\mathrm{w}$ tym przypadku również tekst psalmu z innym horyzontem. Chodzi tu o egzegezę, jaką w tym czasie stosowano.

Trzeba tu odwołać się do Piotra Lombarda i jego dzieła In totum psalterii commentarii (Petrus Lombardus 1133-1138). W wezwaniach psalmu, w dramatycznym wołaniu podmiotu lirycznego komentator odczytuje przede wszystkim krzyk Chrystusa, który wchodzi w mękę. Chrystus poprzez swoją śmierć upodabnia człowieka do siebie. Piotr Lombard, komentując werset czwarty, psalmu 68 widzi w nim Chrystusa ukrzyżowanego. Chrystus konfrontuje się ze swoimi oprawcami. Ich niegodziwość jest odczytana jako niegodziwość człowieka. Konfrontacja obrazu miniaturowego - Ukrzyżowania z dziełem egzegetycznym - z komentarzem Piotra Lombarda owocuje wspólnością znaczeń i przekonań, co więcej odkrywa właściwy głęboki sens obrazu ściśle powiązanego $z$ tekstem psalmu. Dlaczego jednak w ten sposób egzegeza XII stulecia odczytała psalm 68, stosowany od dawna w indywidualnej modlitwie? Jest to pytanie o sens pełniejszy, a nawet już pełny. Odpowiedzi na to pytanie może udzielić skierowane w głąb przeszłości poszukiwanie tekstów egzegezy, które mogą w podobny sposób rozumieć tekst tego psalmu.

Komentarz Piotra Lombarda nie wyczerpuje się jednak w chrystologicznym, typologicznym odczytaniu psalmu. Lwią część tekstu zajmują interpretacje tropologiczne i chrystianologiczne. One jednak nie są obecne w przekazie miniatury. Oprócz tego odnajdujemy w strukturze Ukrzyżowania pewne symptomy, które odsyłają do innej dziedziny. Można wiec zestawić miniaturę z innym horyzontem. 


\section{HERMENEUTYKA DUCHOWA:}

\section{KWATERA Z WYŻSZEGO BRODU}

Kwatera ołtarza z cysterskiego z około 1350 r. z opactwa w Wyższym Brodzie (Vyšší Brod) przedstawia Oplakiwanie (il. 3). Struktura tego obrazu ujawnia jego funkcję. Pion krzyża jest zestawiony z poziomem martwego ciała Chrystusa spoczywającego na łonie Matki oraz na kolanach trzech pozostałych osób. (Pešina passim; Fajt i Chlumská passim). Układ ciała Chrystusa ma na celu ekspozycję - wszystkie osoby podtrzymujące z szacunkiem ciało mistrza stanowią niezbędne elementy owej prezentacji. Czy jednak chodzi o samo ciało? Wydaje się, że nie. Dostrzegamy tam bowiem detale przyciągające uwagę. Są nimi rany - rana boku, rana lewej ręki i rana prawej stopy. Ciało zostało ułożone w pozycji półleżącej po to, aby wyeksponować rany. Ujawniono jedynie trzy rany usytuowane $w$ jednej, poziomej linii, aby ustanowić jedynie trzy newralgiczne punkty medytacji. Ale dlaczego skupiono uwagę jedynie na trzech ranach? Aby odpowiedzieć na to pytanie, należy zestawić przedstawienie z Wyższego Brodu z duchowością cystersów.

Horyzontem będzie duchowe dziedzictwo cystersów, dlatego najpierw należy skierować uwagę badawczą na teksty Bernarda z Clairvaux. Sermones in cantica canticorum przynoszą nam ważny obraz. Są nimi foramina petrae, w których chroni się columba, czyli dusza, pojęta jako osoba wchodząca w relacją z Bogiem. W tych rozpadlinach Bernard rozpoznał rany Chrystusa, ponieważ skałą jest Chrystus. W dalszych rozważaniach komentator stwierdza, że właśnie w ranach Chrystusa słaby człowiek może znaleźć ratunek i bezpieczeństwo (Bernard de Clairvaux 243-259). Człowiek nawet w sytuacji uznania swej grzeszności nie powinien popadać w przygnębienie. W ranach Chrystusa znajdzie on bowiem dostęp do wnętrzności miłosierdzia. Gwóźdź przebił ciało, aby odsłonić wnętrzności Chrystusa i jego bogactwo miłosierdzia. Jego wnętrzności ukazują dobroć i miłość Boga.

Konfrontacja przedstawienia, wydawałoby się typowego i powtarzalnego, z duchowością cystersów przynosi nowe zrozumienie i rzuca światło na sens obrazu. Klasztor w Wyższym Brodzie był przecież opactwem cysterskim. Rany na ciele Chrystusa zdjętym z krzyża ujęte w karby systemu wizualnego, nastawionego na wzrokową komunikację, spotykają się $\mathrm{z}$ opisem i rozumieniem ran Chrystusa w myśli jednego z mistrzów mistyki cysterskiej. To spotkanie odkrywa sens ran na obrazie. Owym sensem jednak są nie tyle rany, ale to, co widz może w nich doświadczyć. To doświadczenie jest możliwe jedynie dzięki zatoczeniu kręgu ku tekstom Bernarda. 
To jednak doświadczenie ran, zarówno w tekście, jak i na obrazie, prowokuje pytanie: Jakie teksty poprzedziły Bernardowe Sermones in cantica canticorum? Jest to pytanie dążące do uzyskania pogłębionego, a nawet pełnego sensu.

HERMENEUTYKA TEOLOGICZNO-POLITYCZNA:

MINIATURA Z EWANGELIARZA Z PRZEDSTAWIENIEM OTTONA III

Miniatura $\mathrm{z}$ Ewangeliarza $\mathrm{z}$ lat 988-1001 niesie zadziwiający obraz władcy (München, Bayerische Staatsbibliothek, Clm 4453) (Mayr-Harting passim; Das Evangeliar passim) (il. 4). Otto III, król Germanii i cesarz rzymski zasiada na tronie $\mathrm{z}$ podnóżkiem i pod baldachimem. Odziany w specjalny rodzaj dalmatyki, płaszcz oraz obdarzony insygniami jawi się jako wyjątkowa osoba. Jest bowiem usytuowany w centrum i w strefie powyżej dwóch uprzywilejowanych grup ludzi - biskupów i książąt. Struktura wizualna przedstawienia ustanawia dystans między Ottonem a przełożonymi Kościoła (metropolici) i przywódcami lokalnych terytoriów (książęta). Król i cesarz jawi się jako osoba oddalona od rzeczywistości ziemskiej, od uwarunkowań zarówno politycznych, jak i kościelnych. Gdzie jednak znajduje się źródło takiej pozycji władcy? Pomocą przy odpowiedzi będzie tutaj zespół doktryn opisujących relację władcy do rzeczywistości nadprzyrodzonych (Scattola 39-84). Należy więc usytuować tę miniaturę pośrodku systemu poglądów zwanych teologią polityczną.

Jeden z jej protagonistów, Hinkmar z Reims, uznawał, że akt namaszczenia jest konstytutywnym aktem kreującym władcę (Hincmarus Rhemensis kol. 807). Ten jednak pogląd jest wtórny w stosunku do pewnej rzeczywistości, która odkrywa sens przedstawienia cesarza Ottona w miniaturze. Jest on namaszczony, aby na mocy łaski Bożej rządzić powierzonym mu ludem Bożym. Namaszczenie Ottona ma taki walor jak namaszczenie starotestamentowych królów, proroków i kapłanów. Smaragdus w sposób systematyczny opisał charakterystyki nowo namaszczonego króla: jest on powołany przez Boga, namaszczony przez Niego krzyżmem i ustanowiony synem (Smaragdus S. Michaelis kol. 931-970). Thietmar z Merseburga twierdził, że cesarz na mocy namaszczenia i koronacji posiada godność przewyższającą zwykłą godność ludzką. Wynika z tego, że nie jest niczym dziwnym, że biskupi stoją poniżej cesarza i króla (Kronika Thietmara 16). Podlegają oni bowiem tylko jemu samemu. Odwzorowuje on samego Chrystusa. Rzeczy- 
wiście, poglądy, z którymi zostało skonfrontowane nasze przedstawienie, pozwalają choć częściowo odkryć sens tejże miniatury.

Należy jednak postawić pytanie o wszystko to, co poprzedziło zespół poglądów ustanawiających władcę osobą poświęconą Bogu. To pytanie odsyła do wypowiedzi poprzedzających te już przeanalizowane. Trzeba też zapytać o istnienie aktu kultowego, który nadawał władcy opisaną pozycję. Tym samym można skonfrontować miniaturę z horyzontem liturgicznym.

\section{HERMENUTYKA, CZYLI ZWROT KU TRADYCJI}

Jakie są konsekwencje usytuowania przedmiotu badań w relacji do horyzontu? Pierwszą konsekwencją, która staje się widoczna, jest konieczność zmiany postawy badacza. Otóż badacz, wychodząc ze wstępnego przekonania o strukturze i jakościach dzieła sztuki, musi zmienić całkowicie swoje nastawienie i od badania sztuki przejść do badania horyzontu. Okazuje się bowiem, że sens, choć tylko częściowy, dzieła może odnaleźć właśnie w zasobach horyzontu, w jego autonomii, w jego swoistości. Nie odbywa się to jednak automatycznie. Odkrywanie sensu rozpoczyna się dokładnego oglądu i rozpoznania zasobów, jakości i wartości horyzontu. Następnie trzeba podjąć selekcję i dokonać aktu wyboru, aby znaleźć moment przylegający do pewnej tylko wyodrębnionej rzeczywistości horyzontu. Towarzyszyć temu musi odkrycie zasad i sposobów działania właściwych dziedzinie, która została wybrana $\mathrm{z}$ horyzontu całościowego przez badacza do konfrontacji $\mathrm{z}$ naszym dziełem.

Z drugiej strony badacz stwierdza, że przedzierając się na linii spiralnej przez zasoby horyzontu, wchodzi w kręgi następnej spirali, która prowadzi go poprzez coraz głębsze warstwy samego przedmiotu uznanego za horyzont. Wymogi zrozumienia sztuki domagają się bowiem zrozumienia tej dziedziny, z którą dzieło sztuki zostało skonfrontowane. Tak wiec w pewnym momencie odkrywanie sensu dzieła sztuki domaga się odkrywania sensu sfery, wobec której zostało ono postawione.

Horyzont bowiem nie jest granicą poznania, nie wyczerpuje też sensu. Powyższe analizy dzieł sztuki wykazały, że znalezienie momentu zbieżnego dzieła i horyzontu, takich jak przedstawienie Ukrzyżowania i moment consecratio, rany Chrystusa - przedstawione i medytowane, Męka odczytana w psalmie i wizualizowana $\mathrm{w}$ miniaturze, nie wygaszają pytań i nie powstrzymują biegu dalszych poszukiwań. Kierunek tych poszukiwań jest wy- 
znaczony przez zasoby, struktury, właściwości horyzontu, do których dotarła spiralna linia. W tym momencie rozpoczyna ona bieg ku rzeczywistościom poprzedzających współczesny kształt horyzontu. W liturgii prowadzi ona poprzez struktury i algorytmy celebracji eucharystycznej poprzedzające kształt missae XII i XIII wieku aż do pierwotnej liturgii i do opisu Ostatniej Wieczerzy w Ewangeliach synoptycznych i listach Pawłowych. W egzegezie prowadzi ona do odczytania uprzednich tekstów interpretujących Księgę Psalmów, aż do Enarrationes in Psalmos Augustyna. Podobnie też odczytywanie Sermones in cantica canticorum będzie się domagać uprzednich odczytań i interpretacji. W duchowości poszukiwać się będzie tekstów, czyli świadectw mistycznych doświadczeń, zbliżonych do tych właściwych Bernardowi, ale wcześniejszych od jego doświadczeń i jego pism. Mamy do czynienia z poszukiwaniem poprzedzających jakości i wartości, które stoją u podłoża obecnego tekstu, współczesnego zestawianemu z nim dziełu sztuki.

Pytanie, które się nasuwa, wydaje się stawiać granice badaniom historyczno-artystycznym i ich hermeneutyce. Czy jednak te dalsze badania nie opuszczają koniecznych granic historii sztuki? Czy są niezbędne dla zrozumienia dzieła sztuki średniowiecznej? Z pomocą przychodzi nam Gadamerowskie pojęcie tradycji. Po dokonaniu wielokrotnego odniesienia do horyzontu, właściwe jest zastosowanie pojęcia tradycji i odniesienia do niej dzieła i jego zasobów. Tradycja jest pewnego rodzaju autorytetem, przyjmowanym dobrowolnie. Gadamer określa ją jako rację historycznego istnienia i trwania wartości (386-388). Filozof ten uznaje tradycję za coś przyjmowanego dobrowolnie, nawet obdarzonego momentem wolności. Tradycja nie jest bezwładnością, nie rozwija się samoistnie, lecz potrzebuje potwierdzenia, ujęcia tego, co najistotniejsze, i aktywnego stosowania, owocującego coraz to nowymi tekstami i dziełami (Gadamer 387-388). Zgadza się to z doświadczeniem zmagania się z tradycją lub tradycjami, które zdają się być zawsze zmaganiem o to, co najistotniejsze, najcenniejsze, $z$ walką $o$ to, co należy zachować i przenieść, a co należy odrzucić.

Relacja do tradycji opiera się na kolistej albo spiralnej strukturze zrozumienia. Hermeneutyka poszukuje nieustannie pełnego zrozumienia, zakłada jednak najpierw „wstępne uchwycenie pełni”. Pierwszym wszakże ruchem kolistym czy nawet spiralnym jest ruch ku horyzontowi. Wyjście więc poza horyzont dotykany linią spiralną albo kolistą prowadzi nas ku tradycji, momentom historycznym, które współgrają z zasadniczym jego zasobem. 


\section{TRADYCJA A SWOISTOŚĆ DZIEŁA SZTUKI}

Czy jednak dotykanie koncentrycznymi kręgami kolejnych momentów historycznych tradycji pozbawia historię sztuki jej pierwotnej hermeneutyki i domaga się przyjęcia hermeneutyk właściwych dla odpowiednich dziedzin horyzontu - Biblii, liturgii, duchowości, teologii politycznej? Czy nie istnieje niebezpieczeństwo porzucenia dzieła sztuki z jego odrębnością, swoistością i niepowtarzalnością plastyczności i wizualności, a potraktowania go jedynie jako nośnika idei, doświadczeń mistycznych rozwiązań egzegetycznych, zdań doktrynalnych? W tej sytuacji pojawia się nowe, bardzo ważne pytanie: czy zakreślenie kręgów najpierw ku horyzontowi, a następnie ku momentom tradycji nie jest rezygnacją z własnej hermeneutyki dzieła sztuki średniowiecznej i wyrażeniem zgody na użycie hermeneutyki obcej, właściwej dziedzinie horyzontu, a następnie odpowiadającej mu tradycji, czyli egzegezie, liturgii, teologii politycznej czy duchowości? Istnieje przeświadczenie, że w momencie otwarcia najpierw na horyzont, a następnie na tradycję należy zanegować hermeneutykę własną sztuki, a przyjąc hermeneutykę właściwą przedmiotowi odniesienia na horyzoncie $\mathrm{i}$ w tradycji, ponieważ inaczej nie będzie można zrozumieć tego, co dzieło sztuki niesie, i zostanie udaremnione odnalezienie sensu. Zanegowanie własnej hermeneutyki miałoby się wiązać z wzięciem w nawias całej sfery stylistycznej, plastycznej, kompozycyjnej, wizualnej, również technologicznej. Istnieje bowiem kolejne przekonanie, a może nawet uprzedzenie, że te właśnie sfery dzieła sztuki nie mają znaczenia dla przekazu idei, wartości, które dzieło sztuki w sobie niesie. Można jednak przywołać pojęcie, które pozwoli nam rozwiązać ten jawiący się problem.

Hans-Georg Gadamer wprowadził pewne ważne pojęcie. Jest nim sens przynależności (Gadamer 405-406). Jest to moment tradycji, którego dotykamy w badaniach. Ten moment wypełnia się, gdy stwierdzamy wspólność podstawowych przekonań. Dokonuje się to w momencie, gdy doświadczając podstawowych, bazowych wartości, szukamy w historii podobnych wartości, które mogą nasze wstępne uchwycenie pełni poszerzyć i pogłębić. Można tu zastosować inne pojęcia filozofa, mianowicie „mieć-do-czynienia”. Pozwala to odkryć, że dzieło „ma-do-czynienia-z-rzeczą”, to znaczy zachowuje wspólność z tekstami, strukturami, jakościami, wartościami, treściami tradycji, to znaczy z tym wszystkim na linii historii, do czego zostało odniesione, po skonfrontowaniu $\mathrm{z}$ horyzontem $\mathrm{w}$ drodze po kręgach, a raczej po spirali. Wydaje się, ze należy tu rozumieć jako respekt dla wszystkiego, co stanowi o właściwości dzieła sztuki. 
Sens przynależności pozwala wstępnie odkryć, że owa wspólność dzieła i tradycji wpływa na kształt dzieła, jago wizualność i swoistość. Jest to jednak stwierdzenie początkowe, niepełne i zawierające wiele luk. Czy rzeczywiście przynależność wpływa na jakość i swoistość dzieła? Odpowiedź na to pytanie będzie przedmiotem dalszych badań.

\section{PODSUMOWANIE}

Poszukiwanie hermeneutyki, która byłaby właściwa do badania dzieł sztuki średniowiecznej, rozpoczęto od analizy wstępnego oglądu i wstępnego poznania dzieła. Jest ono punktem wyjścia kolistego ruchu poznawczego. Nie prowadzi on jednak od razu, jak to zarysował Hans-Georg Gadamer, ku tradycji, lecz ku horyzontowi, który jest wybrany przez badacza w zgodzie z pierwotnym poznaniem. Horyzont i odniesienie do niego dzieła jest elementem badań trudnym do przecenienia. Spiralny powrót ku horyzontowi nie przynosi jednak pełni poznania dzieła i pełni sensu. Domaga się on wyjścia i skierowania ku tradycji. Tam można znaleźć wspólność przekonań, obecną zarówno w dziele, jak i w tradycji. Ta wspólność owocuje odkryciem sensu. Problemem pozostaje kwestia rezygnacji z własnej hermeneutyki sztuki na rzecz hermeneutyk właściwych do badania tradycji. Sens jednak przynależności, czyli moment dotknięcia tradycji i dzieła z jego jakościami, może stanowić pewne rozwiązanie tego problemu.

\section{BIBLIOGRAFIA}

\section{ŹRÓDŁA}

Bernard de Clairvaux. Sermons sur la Cantique de Cantique, tome IV, sermons 51-68, le texte latin, introduction, traduction et notes Paul Verdeyen et Rafaello Fasetta, CERF, 2005, ss. 243-259.

Gadamer, Hans-Georg. Prawda i metoda. Zarys hermeneutyki filozoficznej. Tłum. Bogdan Baran, Wydawnictwo Naukowe PWN, 2007.

Heidegger Martin. Bycie i czas. Tłum. Bogdan Baran, Wydawnictwo Naukowe PWN 2008.

Hincmarus Rhemensis, „Coronationes regiae”. Patrologiae cursus completus. Series Latina [PL], t. 125, red. Jacques Paul Migne, Parisiis 1852, kol. 807.

Petrus Lombardus. „In totum psalterium commentarii”. Patrologiae cursus completus. Series Latina [PL], t. 191, red. Jacques Paul Migne, Parisiis 1854, kol. 431-1296D (1133-1138). 
Smaragdus S. Michaelis. „Via regia”. Patrologiae cursus completus. Series Latina [PL], t. 102, red. Jacques Paul Migne, Parisiis 1851, kol. 931-970.

Kronika Thietmara. Tłum., wstęp i przypisy Marian Zygmunt Jedlicki, Universitas, 2002.

\section{OPRACOWANIA}

Bätschmann, Oskar. Einführung in die kunstgeschichtliche Hermeneutik. Die Auslegung von Bildern. Darmstadt Wissenschaftliche Buchgesselschaft, 2001.

Bätschmann, Oskar. „Beiträge zu einem Übergand von der Ikonologie zur kunstgeschichtlichen Hermeneutik". Bildende Kunst als Zeichensystem. Band 1: Ikonographie und Ikonologie. Theorien-Entwicklung-Probleme. Verlag DuMont, 1979, ss. 460-484.

Boehm, Gottfried. „Zu einer Hermeneutik des Bildes”. Seminar: Die Hermeneutik und die Wissenschaft, red. Hans-Georg Gadamer i Gottfried Boehm, Suhrkamp, 1978, ss. 444- 471.

Bryl, Mariusz. „Płaszczyzna ogląd absolut. Inspiracje hermeneutyczne we współczesnej historii sztuki". Artium Quaestiones, t. 6, 1993, ss. 55-84.

Bryl, Mariusz. „[Rozdz. VIII] Hermeneutyki w historii sztuki między alternatywą a przyswojeniem". Suwerenność dyscypliny. Polemiczna historia stuki od 1970 roku. Wydawnictwo Naukowe UAM, 2008 , ss. 433-494.

Das Evangeliar Ottos III Clm 4453 der Bayerischen Staatsbibliothek München, red. Florentine Mütherich i Karl Dachs, Prestel, 2001.

Fajt, Jiří, i Štěpánka Chlumská. Čechy a střední Evropa 1200-1550. Dlouhodobá expozice sbirky starého umění Národni galerie v Praze v klášteře sv. Anežky České. Národní Galerie, 2006.

Haake, Michał. „Jednostka wobec historii. Portret generała Henryka Dembińskiego Henryka Rodakowskiego". Artium Quaestiones, t. 12, 2001, ss. 25-84.

Haake, Michał. „Obraz w kole rozumienia”. Artium Quaestiones, t. 20, 2009, ss. 141-170.

Haake, Michał. „Powołanie Mateusza Caravaggia. Studium z hermeneutyki obrazu”. Artium Quaestiones, t. 18, 2007, ss. 37-115.

Imdahl, Max. Giotto, Zur Frage der ikonischen Sinnstruktur. Carl Friedrich von Siemens Stiftung, 1979 (pol. „Giotto. Z zagadnień ikonicznej struktury sensu”. Tłum. Tadeusz Żuchowski. Perspektywy wspótczesnej historii sztuki. Antologia przekładów „Artium Quaestiones", red. Mariusz Bryl, Piotr Januszewski, Piotr Piotrowski i Wojciech Suchocki, Wydawnictwo Naukowe UAM, 2009, ss. 111-138.

Imdahl, Max. „Kontingenz, Komposition, Providenz. Zur Anschauung eines Bildes von Giotto”. Anschauung als ästhetische Kathegorie: Neue Hefte für Philosophie, t. 19/19, 1980, ss. 151-177.

Imdahl, Max. „Über eine narrative Strukturen in den Arenafresken Giottos”. Geschichte - Ereignis und Erzählung, red. Reinhart Koselleck i Wolf-Dieter Stempel, (Poetik und Hermeneutik V), Verlag Fink, 1973, ss. 155-173.

Jungmann, Josef Andreas. Missarum solemnia. Eine genetische Erklärung der römischen Messe. Bd. 2, Herder, 1952.

Martimort, Aimé-Georges. La Chiesa in preghiera. II. Eucaristia, red. wyd, włoskiego Adelio Biazzi, Queriniana, 1985.

Mayr-Harting, Henry. Ottonian Book Illumination: An Historical Study. Part I: Themes, Harvey Miller Brepols 1999, pp. 1598-159.

Meyer, Hans Bernhard. Eucharistie. Geschichte, Theologie, Pastoral. Friedrich Pustet, 1989. 
Pešina, Jaroslav. Mistr Vysebrodského cyklu. Odeon, 1982.

Skubiszewski, Piotr. „Programy obrazowe kielichów i paten romańskich”. Rocznik Historii Sztu$k i$, t. 13, 1981, ss. 77-81.

Scattola, Merio. Teologia polityczna. Tłum. Paweł Borkowski, Instytut Wydawniczy PAX, 2011.

Tabor, Dariusz. „Od lectio divina do dwóch sensów Pisma. Refleksy cysterskiej egzegezy w Psałterzu trzebnickim IF 440". Dzieje i kultura cystersów w Polsce 2, red. Marcin Starzyński i Dariusz Tabor, Wydawnictwo Uniwersytetu Papieskiego Jana Pawła II w Krakowie, 2018, ss. 179-194.

Tabor, Dariusz, „Psałterz trzebnicki: między egzegezą a duchowością”. Cysterki w dziejach i kulturze ziem polskich, dawnej Rzeczypospolitej i Europy Środkowej. Materiały z siódmej Międzynarodowej Konferencji Cystersologów, Trzebnica 18-21 września 2002, red. Andrzej Marek Wyrwa, Antoni Kiełbasa i Józef Swastek, Wydawnictwo Poznańskie, 2004, ss. 108-120.

\section{HERMENEUTYKA SZTUKI ŚREDNIOWIECZNEJ: WŁASNA LUB ZAPOŻYCZONA? PRÓBA ZASTOSOWANIA PROCEDUR HERMENEUTYKI FILOZOFICZNEJ DO BADAŃ NAD SZTUKĄ}

Streszczenie

Hermeneutyka Maxa Imdahla wyróżnia widzenie rozpoznające temat ikonograficzny oraz widzenie widzące szczególną strukturę obrazu. Hermeneutyka Godfrieda Böhme jest przekładem zamiany medium wizualnego na medium obrazowe, przy znalezieniu tego, co obu wspólne (Bildlichkeit). Oskar Bätschmann odrzuca redukcje, jakim poddaje dzieło sztuki ikonologia i dąży do odkrycia tego, co dzieło samo z siebie ujawnia. Te hermeneutyki kierują ku wyjątkowej swoistej, nieredukowalnej do dyskursu strukturze dzieła. Badanie sztuki średniowiecznej wymaga wyjścia poza ścisłą strukturę wizualną. Podjęto próbę zastosowania procedur właściwych hermeneutyce filozoficznej Hansa Georga Gadamera. Jej podstawą jest istnienie przedpoznania, rzeczywistej wiedzy na temat dzieła oraz stosowanie języka wykluczającego bezrefleksyjne stosowanie kodów. Droga badawcza dalej skierowana jest ku tradycji. W procesie badanie sztuki średniowiecznej nie można od razu zastosować odniesienia dzieła do tradycji. Trzeba postawić dzieło wobec wybranego horyzontu, rzeczywistości, które je otacza, w relacji do horyzontu liturgicznego, egzegetycznego, duchowego i teologiczno-politycznego. Linia spirali biegnie ku horyzontowi, ku momentom tradycji na linii czasu. Konfrontacja z tradycją, to odnalezienie sensu przynależności, momentu w tradycji, momentu wspólności podstawowych zawartości dzieła i rzeczywistości, należących do tradycji. Zastosowanie pojęcia sensu przynależności nie spowoduje utraty własnej hermeneutyki sztuki na rzecz hermeneutyk właściwych dla zawartości tradycji.

Słowa kluczowe: hermeneutyka; hermeneutyka historii sztuki; krąg hermeneutyczny; sztuka średniowieczna; horyzont hermeneutyczny. 


\title{
THE HERMENEUTICS OF MEDIEVAL ART: OWN OR LOANED? AN ATTEMPT TO APPLY THE PROCEDURES OF PHILOSOPHICAL HERMENEUTICS IN ART RESEARCH
}

\begin{abstract}
S u m m ary
Max Imdahl's hermeneutics distinguishes seeing that recognizes an iconographic subject and one that sees a specific structure of an image. Godfried Böhme's hermeneutics is a transposition of the visual medium to the pictorial medium, while finding what both have in common, i.e. Bildlichkeit. Oskar Bätschmann's hermenutics rejects the reductions done by iconology to a work of art and seeks to discover what the work of art reveals by itself. These three hermeneutics direct the researcher's attention towards the unique, specific structure of the work, irreducible to discourse. The study of medieval art requires going beyond the strict visual structure. An attempt was made to apply procedures inherent in the philosophical hermeneutics of Hans-Georg Gadamer. The basis of this hermeneutics is the existence of pre-cognition, which is the actual knowledge of the work, and the use of language that excludes the unreflective use of codes. A circular research path leads from pre-recognition to tradition. However, in the process of studying medieval art, the reference of a work to tradition cannot be made straight away. A given work must be placed against the horizon which is the reality surrounding it, namely in relation to the liturgical, exegetical, spiritual and theological-political horizons. The spiral line runs then towards the horizon, spiraling into moments of the tradition along the timeline. A confrontation with tradition is finding the sense of belonging, a moment in tradition, a moment of commonality of the basic contents of both the work and the reality, which both belong to tradition. Applying the notion of a sense of belonging will not result in the loss of its own hermeneutics of art in favor of hermeneutics appropriate to the content of tradition.
\end{abstract}

Keywords: hermeneutics; hermeneutics of art history; hermeneutic circle; medieval art; hermeneutic horizon. 


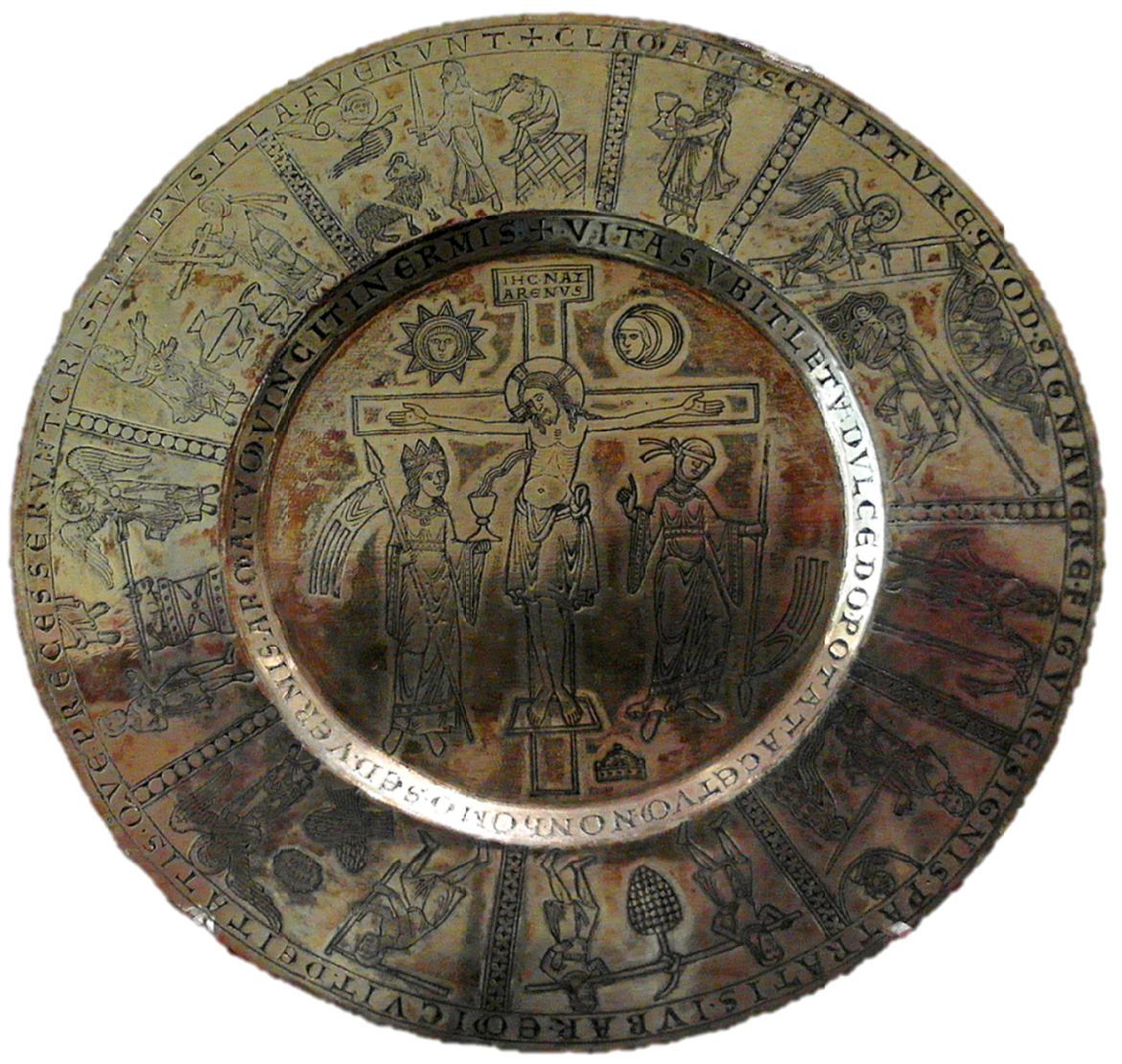

1. Patena z Trzemeszna, około 1180 r.,

Gniezno, Muzeum Archidiecezjalne 


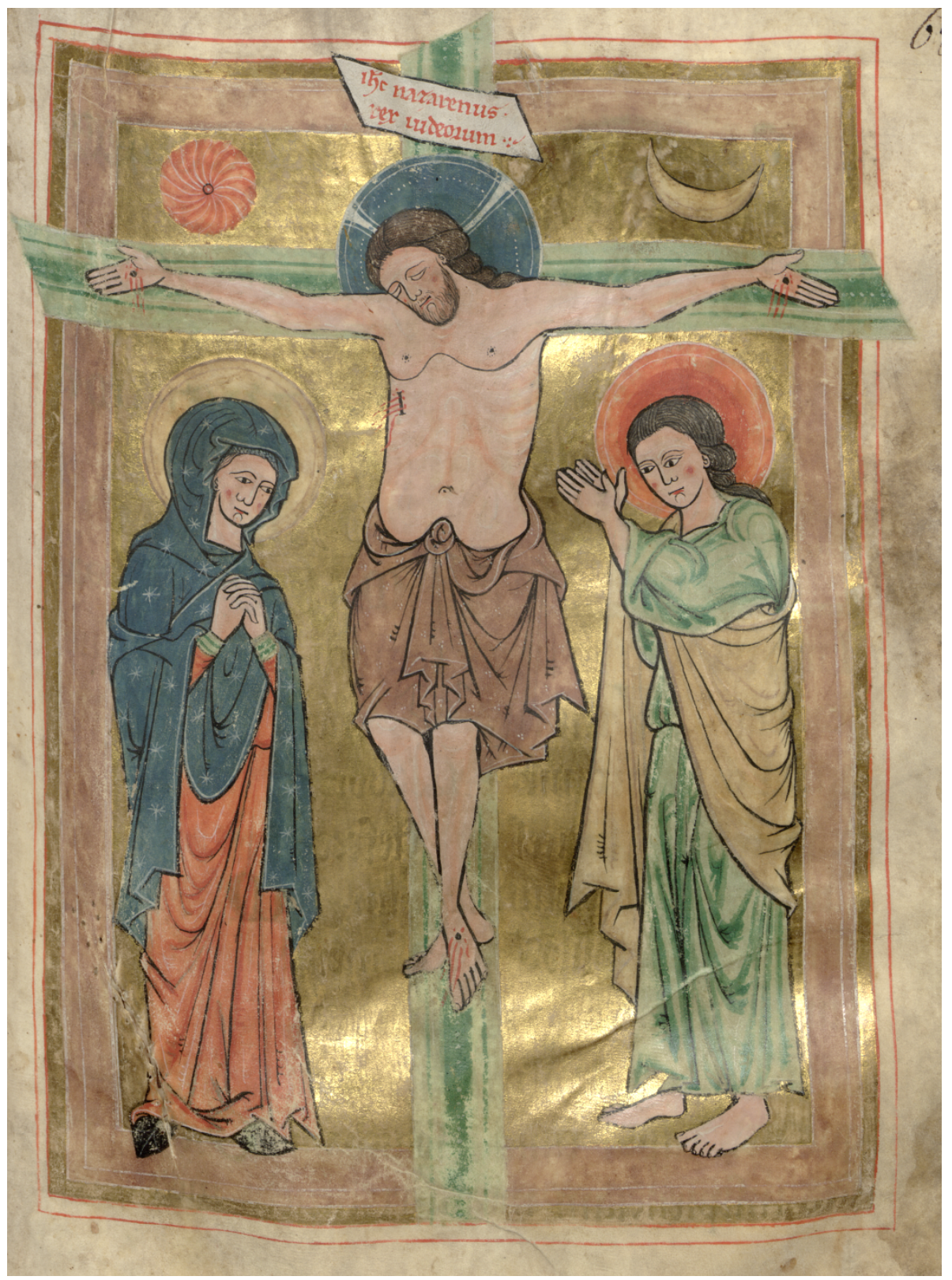

2. Ukrzyżowanie, Psałterz trzebnicki, 68 r, lata 30 . XIII wieku, Wrocław, Biblioteka Uniwersytecka IF 440 


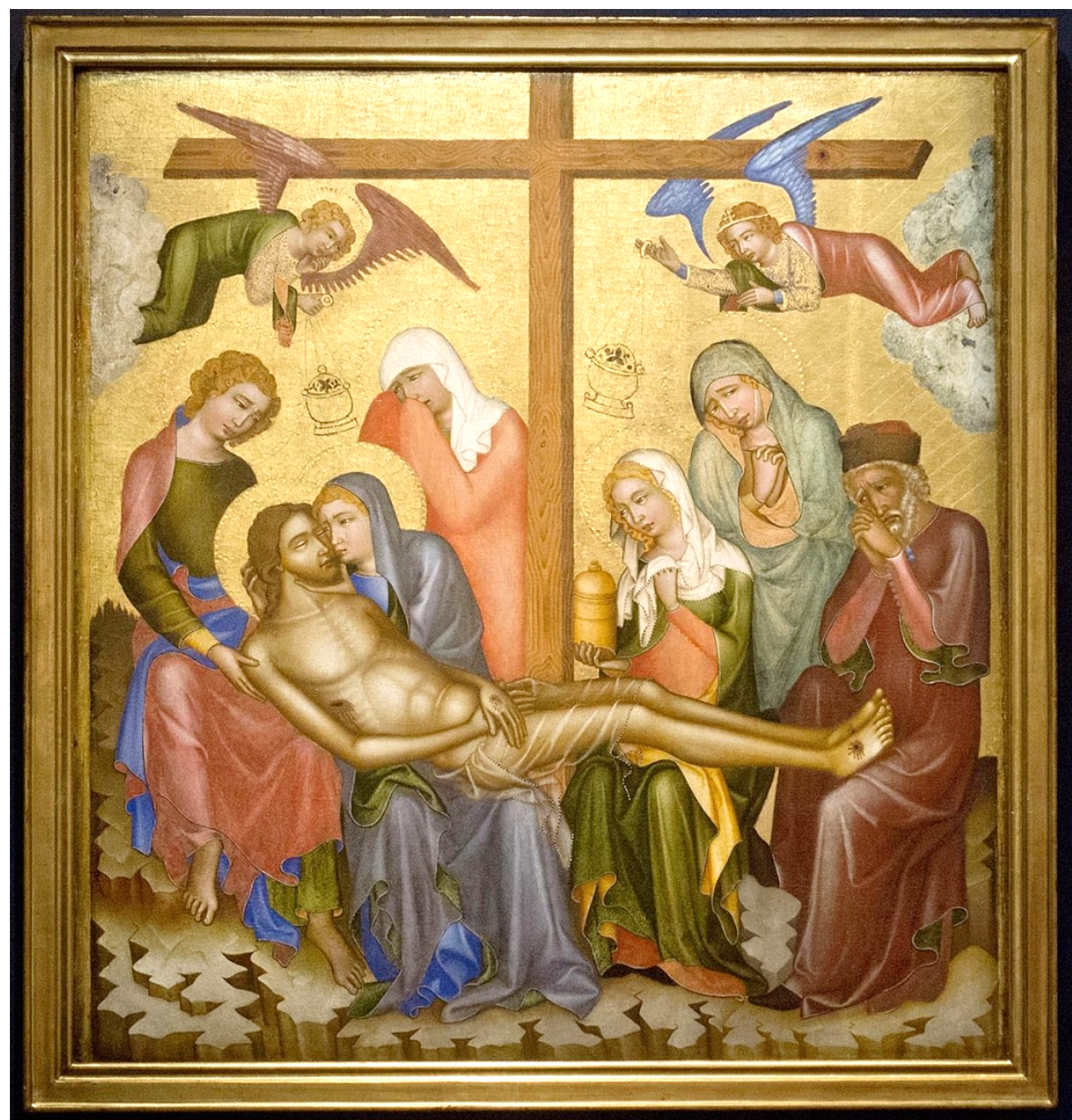

3. Opłakiwanie, kwatera retabulum z Wyższego Brodu (Vyšší Brod), ok. 1350, Praga, Národní galerie 


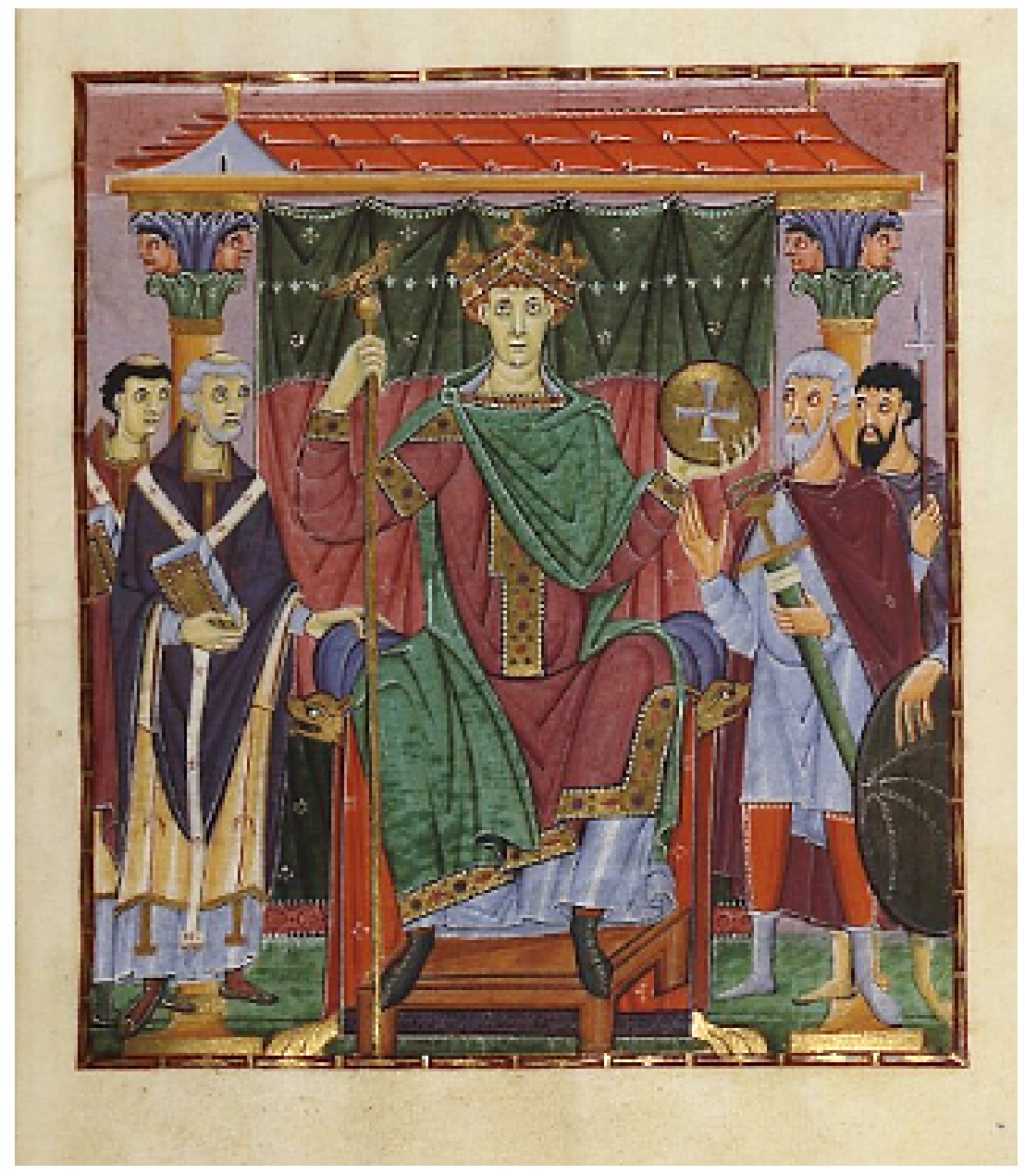

Cesarz Otton III, miniatura Ewangeliarza, około 1000 r., Monachium, Bayerische Staatsbibliothek, Clm 4453 
